Diklus: Jurnal Pendidikan Luar Sekolah, 1 (1), Maret 2017, 107

Abdul Rohman Nurfaal

\title{
PENYELENGGARAAN PROGRAM PELATIHAN TATA BUSANA DI BALAI PERLINDUNGAN DAN REHABILITASI SOSIAL WANITA (BPRSW) DAERAH ISTIMEWA YOGYAKARTA (DIY)
}

\section{IMPLEMENTATION OF DRESSMAKING TRAINING PROGRAM IN BALAI PERLINDUNGAN DAN REHABILITASI SOSIAL WANITA (BPRSW) DAERAH ISTIMEWA YOGYAKARTA}

\author{
Oleh: Abdul Rohman Nurfaal, Pendidikan Luar Sekolah, nurfaal@gmail.com
}

\begin{abstract}
Abstrak
Penelitian ini bertujuan untuk memperoleh informasi dan memahami: (1) Perencanaan program pelatihan tata busana di Balai Perlindungan dan Rehabilitasi Sosial Wanita (BPRSW) Daerah Istimewa Yogyakarta (DIY), (2) Pelaksanaan program pelatihan tata busana BPRSW DIY, (3) Evaluasi program pelatihan tata busana BPRSW DIY. Penelitian ini merupakan penelitian deskriptif dengan pendekatan studi kasus. Subjek penelitian ini adalah penyelenggara program pelatihan tata busana di BPRSW DIY, kepala bagian Perlindungan dan Rehabilitasi Sosial, pendamping, instruktur, dan peserta pelatihan (klien) yang sudah lama menempuh program pelatihan. Pengumpulan data dilakukan dengan menggunakan teknik observasi, wawancara, dan dokumentasi. Instrumen utama penelitian yaitu peneliti sendiri yang dibantu dengan pedoman observasi, pedoman wawancara, dan pedoman dokumentasi. Teknik analisis data yang digunakan adalah teknis analisis data komponensional melalui tahapan reduksi, penyajian data, dan vetifikasi data. Teknik keabsahan data yang digunakan yaitu trianggulasi sumber dan trianggulasi metode. Hasil penelitian menunjukkan bahwa: (1) perencanaan meliputi penentuan peserta, materi, media, metode, waktu, sarpras, instruktur, dan waktu. Perencanaan melalui kordinasi penyelenggara dan instruktur. (2) Pada pelaksanaannya, instruktur mempunyai peran penting dalam mengolah komponen-komponen lainnya seperti materi, sarana dan prasarana, media, metode, peserta, serta memanfaatkan waktu. Setiap peserta diberikan materi yang berbeda sesuai dengan pencapaiannya, karena adanya sistem buka tutup. (3) Evaluasi dilakukan di dalam kelas yang menggunakan pengamatan langsung terhadap kinerja peserta serta hasilnya dan evaluasi tri wulan membahas semua komponen-komponen pelatihan. Faktor pendukung program yaitu adanya sumber daya yang saling mendukung seperti pendamping, instruktur, ketersedian sarpras yang mencukupi serta keleluasaan peserta untuk menggunakan sarpras di luar jam belajar. Sedangkan faktor penghambat adanya kualitas sarpras yang berbeda-beda seperti mesin jahit dan bordir, serta kesulitan mencari bahan pendukung yang kompatibel.
\end{abstract}

Kata kunci: penyelenggaraan program, pelatihan tata busana, BPRSW

\section{Abstract}

This research aimed to get infomations and discern (1) plan of dressmaking training program in BPRSW DIY, (2) implementation of dressmaking training program in BPRSW DIY, (3) evaluation of dressmaking training program in BPRSW. This research is descriptive with case study approach. This research subject is the organizer of the dressmaking training program in BPRSW DIY, instructors and trainees (client) that have long been taking the training program. The data was collected by observation, interview, and documentation. The main instrument of reseach is researcher that assisted by observation guidelines, interview guidelines, and documentation guidelines. Data analysis technique used is a technical analysis of the komponensional data through reduction phase, data display, and veritification. Mechanical validity of data used is source triangulation and methods triangulation. The results showed that (1) Plan of program includes participans, teachmaterials, medias, metode, times, facilities and infrastructures, instructors, and times. Plan throughs coordination organizers and instructors. (2) Implementation, the instructors have an important role in the process of other components such as teachmaterials, facilities and infrastructures, medias, methods, participants, and use the time. Each participant is given a different material in accordance with its achievement, because the existence of a system of open lid. (3) Evaluation is 


\section{Diklus:Jurnal Pendidikan Luar Sekolah, 1(1), Maret 2017, 108 \\ Abdul Rohman Nurfaal}

done in the class that use direct observation on performance of the participants and the learning evaluation and evaluation of triwulan discussing all training components. The factors supporting a program is the existence of resources that supports each other. They are escorts, instructors, availability of sufficient leeway and facilities participants to use outside of the study. While the factors restricting the quality of different facilities like sewing machines and embroidery, as well as the difficulty of finding a compatible supporting materials.

Keyswords: implementation programs, dressmaking training, BPRSW

\section{PENDAHULUAN}

Kemiskinan di negara-negara berkembang menjadi masalah yang tidak kunjung selesai, salah satunya di Indonesia. Berdasarkan data dari Badan Pusat Statistik jumlah penduduk miskin di Indonesia pada tahun 2013 yaitu 28.553.930 jiwa, pada tahun 2014 jumlah penduduk miskin yaitu 27.727.780 jiwa, pada tahun 2015 jumlah penduduk miskin yaitu 28.513.570 jiwa (BPS 2016, diakses 18 Juni 2016). Jumlah penduduk miskin pada tahun 2016 menunjukan angka kemiskinan pada level 11,13 \% (BPS, 2016: 109). Data tersebut masih menunjukan besarnya jumlah penduduk miskin di Indonesia. Daerah Istimewa Yogyakarta (DIY) merupakan salah satu provinsi dengan angka kemiskinan cukup tinggi yaitu 13,16\% (BPS, 2016: 114).

Kemiskinan dipandang sebagai ketidakmampuan dari sisi ekonomi untuk memenuhi kebutuhan dasar makanan dan bukan makanan yang diukur dari sisi pengeluaran (BPS, 2016: 110). Kemiskinan tidak hanya menyangkut permasalahan kesejahteraan semata, masalah kemiskinan disebabkan dengan adanya persoalan kerentanan, ketidakberdayaan, tertutupnya akses tehadap peluang kerja, dan sebagainya
(Ambar Tegus Sulistiyani, 2004: 27). Ketidakberdayaan dan tertutupnya akses terhadap kerja akan mengarah pada persoalan pengangguran.

Data pengangguran penduduk DIY pada Bulan Februari 2015 sebanyak 85.500 jiwa dengan angka 4,07 \%, pada Bulan Agustus 2015 jumlah pengangguran sebanyak 80.200 dengan angka 4,07\%, dan pada Bulan Februari 2016 jumlah pengangguran sebanyak 59.000 jiwa dengan angka 2,81 \% (BPS, 2016: 57)

Masalah pengangguran menyebabkan penyimpangan sosial contohnya mencuri, menodong, menjambret, membunuh, dan lainlain. Pada dasarnya setiap manusia mempunyai kebutuhan yang harus dipenuhi agar manusia tersebut mampu bertahan hidup. Ketidak mampuan dalam melakukan usaha yang wajar karena kemampuan yang kurang mendorong manusia pada tindakan krimimal/kejahatan (Kartini Kartono: 2015: 140). Maka penyimpangan sosial mengarah pada tindak kriminal atau tindak kekerasan.

Daerah Istimewa Yogyakarta merupakan salah satu provinsi dengan jumlah kekerasan terhadap wanita yang cukup banyak. Pada tahun 2012 terdapat 15.309 korban, pada tahun 2013 terdapat 15.118 
korban dan pada tahun 2014 terdapat 17.338 korban (Sub Direktorat Statistik Politik dan Keamanan, 2015: 98).

Wanita yang menjadi korban kekerasan adalah bagian dari warga negara Indonesia yang berhak mendapat perlindungan dan kesejahteraaan sosial sesuai dengan UU No 11 Tahun 2009 dan Perpres No 18 Tahun 2014 tentang jaminan kesejahteraan sosial dan jaminan kesejahteraan khusus bagi wanita. BPRSW merupakan lembaga yang berfungsi untuk memberikan perlindungan, pelayanan, dan rehabilitasi sosial dalam rangka membantu permasalahan sosialnya.

Layanan berupa Rumah Penanganan Trauma Center (RPTC), bimbingan mental sosial dan bimbingan keterampilan (pelatihan). Pelatihan yaitu kegiatan belajar dan praktek untuk sesuatu tujuan baik, dilakukan secara berulang-ulang dan terusmenerus untuk memperoleh mengembangkan kemampuan, sikap, dan pengetahuan (Saleh Marzuki, 2012: 175). Pelatihan diupayakan untuk membekali peserta (klien) dengan keterampilan praktis agar ketika peserta atau alumni kembali di masyarakat mempunyai kemampuan untuk berperan sebagai masyarakat yang wajar. Salah satu pelatihan yang ada di BPRSW adalah pelatihan tata busana, mengingat bahwa busana merupakan bagian dari kebutuhan sandang yang harus dipenuhi. Maka setiap manusia memerlukan sandang dalam menjalani hidupnya.
Dalam pelatihan program tata busana ada yang perlu diperhatikan untuk melihat kinerja, dan keberhasilan program serta pencapaian tujuan. Dalam hal ini peranan dari komponen program dan manajemen sangat berpengaruh dalam keberhasilan program, termasuk program pelatihan tata busana.

Pada penyelenggaraan kegiatan rehabilitasi sosial BPRSW Yogyakarta menerapkan sistem rekruitmen buka tutup, artinya selama kuota klien di BPRSW masih tersedia maka akan ada perekrutan klien baru. Kuota yang tersedia untuk melayani klien di BPRSW 65 Klien. Sistem buka tutup menjadi masalah karena klien/peserta yang baru masuk akan mengalami banyak kertinggaalan materi dari klien/peserta yang sudah lama.

Pada penyelenggaraan kegiatan rehabilitasi sosial BPRSW Yogyakarta menerapkan sistem rekruitmen buka tutup, artinya selama kuota klien di BPRSW masih tersedia maka akan ada perekrutan klien baru. Kuota yang tersedia untuk melayani klien di BPRSW 65 Klien. Sistem buka tutup menjadi masalah karena klien/peserta yang baru masuk akan mengalami banyak kertinggaalan materi dari klien/peserta yang sudah lama.

Berdasarkan uraian di atas, pelaksanaan program pelatihan tata busana menggunakan sistem buka tutup menarik untuk dikaji, oleh karena itu, peneliti tertarik untuk melakukan penelitian terkait dengan penyelenggaraan program pelatihan tata busana di BPRSW DIY. Penelitian ini diharapkan mampu menemukan temuan 
menarik yang dapat dijadikan sebagai bahan masukan untuk memperbaiki maupun mengembangkan program pelatihan tata busana di BPRSW DIY.

\section{METODE}

\section{Jenis Penelitian}

Penelitian ini merupakan penelitian penelitian deskriptif dengan pendekatan studi kasus.

\section{Setting Penelitian}

Penelitian akan dilaksanakan di BPRSW DIY yang terletak di Dusun Cokrobedog, Kelurahan Sidoarum, Kecamatan Godean, Kabupaten Sleman.

\section{Subjek Penelitian}

Subjek penelitian ini adalah peserta pelatihan yang sudah lama menempuh program pelatihan tata busana, instruktur, kepala bagian perlindungan dan rehabilitasi sosial (PRS), pendamping program pelatihan tata busana yang bersatus sebagai pekerja sosial maupun sebagai staff PRS.

\section{Teknik Pengumpulan Data dan Instrumen}

\section{Penelitian}

Teknik pengumpulan data yang digunakan dalam pemelitian ini yaitu observasi, wawancara, dan dokumentasi. Intrumen peneletian yaitu peneliti sendiri yang dibantu dengan pedoman observasi, pedoman wawancara, dan pedoman dokumentasi.

\section{Teknik Analisis Data}

Teknik analisis data yang digunakan dalam penelitian ini yaitu analisis komponensional yang melalui tahapan reduksi data, penyajian data dan penarikan kesimpulan atau verifikasi data.

\section{Pengujian Keabsahan Data}

Teknik keabsahan data yang digunakan dalam peneletian ini yaitu trianggulasi sumber dan trianggulasi metode.

\section{Hasil Penelitian serta Pembahasan}

\section{Perencanaan Program Pelatiaahan Tata Busana}

\section{a. Tujuan}

Dalam penyelenggaraan program pelatihan tata busana memiliki tujuan, yaitu :

1) Agar klien menguasai keterampilan menjahit, membordir, membuat pernakpernik, dan mendesain.

2) Agar klien mampu memanfaatkan keterampilan/keahlian yang diperoleh dari program pelatihan tata busana untuk menunjang kebutuhan hidupnya dalam bermasyarakat, tidak terjerumus dengan cara pemenuhan hidup yang salah.

Tujuan program pelatihan tata busana secara tertulis lebih menekankan kepada penguasaan keahlian utama menjahit dan keahlian penunjang yaitu bordir, kerajinan dan desain. Walaupun demikian, pada kenyataannya tidak mungkin suatu keahlian dikuasai tanpa dibarengi dengan pengetahuan. Kemudian dalam proses penguasaan keahliankeahlian teserbut membentuk sikap-sikap yang positif kepada peserta. Dalam praktek penguasaan materi melalui penugasan individu tersebut secara pelahan membentuk sikap ketelitian, ketenangan, kesabaran, keuletan. Sebagai contoh ketika peserta 
mengendalakan gas mesin jahit/bordir/obras memerlukan ketenangan, ketelitian dan tempo yang pas untuk menghasilkan produk yang bermutu. Tujuan program pelatihan tata busana didukung oleh teori yang dikemukakan oleh Ikka Kartika A. Fauzi (2011: 14) sebagai berikut

1) Untuk mengembangkan keahlian, sehingga pekerjaan dapat diselesaikan dengan lebih cepat dan efektif. 2) Untuk mengembangkan pengetahuan, sehingga pekerjaan dapat dikerjakan secara rasional. 3) Untuk mengembangkan sikap, sehingga menimbulkan kemauan dan kerjasama dengan teman-teman, pegawai, dan pimpinan.

\section{b. Rekruitmen}

Sistem rekruitmen yang digunakan yaitu sistem buka tutup, dalam rekruitmen yang menjadi pelaku adalah para pekerja sosial. Pekerja sosial melakukan sosialisasi, kemudian melakukan seleksi dengan kriteria yang sudah ditentukan. Dalam pelaksanaannya ada tiga hal dalam rekruitmen yaitu calon klien yang mendatangi langsung ke kantor BPRSW DIY, mendapat rujukan dari lembaga sosial yang telah bekerja sama, dan laporan dari masyarakat. BPRSW DIY adalah Badan yang bergerak di bidang sosial untuk melayani masyarakat, khususnya wanita yang mengalami permasalahan sosial. Klien adalah peserta pelatihan yang mempunyai karakteristik secara umum yaitu wanita yang mengalami permasalahan sosial.

Berdasarkan hasil temuan yang ada di lapangan sudah sesuai dengan teori yang dikemukakkan oleh Tim Dosen AP UNY
(2011: 52) dan Ikka Kartika A. Fauzi (2011: 27) terkait dengan rekruitmen calon peserta yang meliputi adanya tim khusus rekruitmen, sosialiasasi, pendaftaran dan seleksi yang didasarkan kriteria klien.

\section{c. Instruktur}

Penentuan instruktur yang dipilih harus sesuai dengan kompetensi program yang telah dirumuskan agar peserta pelatihan mampu mencapai tujuan program pelatihan. Dalam memilih instruktur pada program pelatihan tata busana BPRSW adalah bagian seksi perlindungan dan pelayanan rehabilitasi sosial (PRS). instruktur dipilih sesuai dengan kebutuhan bidang yang ada di program pelatihan tata busana, bidang tersebut meliputi bidang jahit, bidang bordir, bidang desain, dan bidang kerajinan. Dalam menemukan orang yang memiliki keahlian yang sesuai dengan bidang yang dibutuhkan yaitu melalui rekomendasi dari pegawai BPRSW maupun seksi PRS langsung.

Pertimbangan lainnya dalam memilih instruktur adalah orang yang telaten/tekun/sabar. Tahapan selanjutnya adalah penetapan calon instruktur melalui rapat triwulan dan tahap seleksi non tes serta penerimaan. Hasil temuan tersebut didukung oleh Oemar Hamalik (2007: 127) yang menyatakan bahwa instruktur dipilih harus sesuai dengan kompetensi program yang telah dirumuskan agar peserta pelatihan mampu mencapai tujuan program pelatihan.

\section{d. Materi, Metode, Sarana dan Prasarana}




\section{Diklus : Jurnal Pendidikan Luar Sekolah, 1(1), Maret 2017, 112 \\ Abdul Rohman Nurfaal}

Penetapan materi, metode, media, sarana dan prasarana. Dalam menetapkan keempat hal tersebut sesuai dengan kebutuhan yang ada dan sinkronisasi antar komponen tersebut termasuk tujuan. Kebutuhan dapat diketahui dengan menanyakan kepada instruktur, yang berarti instruktur memiliki wewenang penuh dalam menentukan rincian keempat komponen tersebut.

Dalam menentukan materi ada dua gaya yang dilakukan oleh instruktur, yang pertama instruktur bidang jahit, bordir, dan desain. Ketiga instruktur tersebut menyusun materi dari hal yang dasar atau dasar-dasar dari ketiga bidang tersebut kemudian materi sifatnya bertingkat, atau materi yang sebelumnya disampaikan adalah fondasi untuk melanjutkan/mempelajari materi berikutnya. Kemudian instruktur bidang kerajinan menetapkan materi sesuai tren yang ada dengan memperhatikan prinsip bahan dan alat ekonomis. Selain kedua hal yang dipertimbangkan oleh keempat instruktur tersebut ada hal lain seperti ketersediaan sarana dan prasarana dan waktu.

Instruktur dalam metode, media, sarana dan prasarana menyesuaikan dengan materi yang ada, secara garis besar metode yang dipakai oleh setiap instruktur adalah praktek, ceramah hanya dilakukan sedikit ketika mengarahkan para peserta. Pada bidang jahit ada sesi ceramah khusus selain saat melakukan pengarahan/pengamatan yaitu ketika menjelaskan mengenai rumus pola. Dalam menetapkan metode, didukung oleh
Ikka Kartika A. Fauzi (2011: 73-74) yang harus memperhatikan tujuan pelatihan, materi, waktu, sarana dan prasarana, kemampuan peserta, dan kemampuan pendidik, sama halnya dengan mentukan media dan sarana dan prasarana yang harus menyesuaikan komponen lainya.

Instruktur memiliki wewenang penuh dalam menentukan keempat komponen tersebut, namun bukan berarti instruktur yang harus menyusun semua hal itu sendiri. Untuk media, dan sarana dan prasarana (alat dan bahan) yang bertugas untuk pengadaannya adalah PRS, sedangkan untuk pemeliharaan dan perawatan sarana dan prasarana terkait dengan adalah bagian TU. PRS dan TU mengadakan hal tersebut sesuai dengan kebutuhan, sedangkan kebutuhan dapat diketahui dengan menanyakan instruktur. secara resmi koordinasi tersebut dilakukan saat rapat triwulan. Jadi semua sumber daya manusia memiliki peran masing-masing untuk mendukung program pelatihan tata busana.

\section{e. Waktu}

Tentunya dalam menentukan materi, instruktur juga memperkirakan waktu yang diperlukan peserta untuk menguasai materi. Dalam menentukan jumlah kasaran waktu yaitu PRS, sedangkan instruktur menyesuaikan waktu yang disediakan oleh PRS untuk menyusun materi.

. Temuan terkait waktu ini didukung oleh pendapat Ikka Kartika A. Fauzi (2011: 115) bahwa waktu pelatihan tergantung pada 


\section{Diklus : Jurnal Pendidikan Luar Sekolah, 1(1), Maret 2017, 113 \\ Abdul Rohman Nurfaal}

kebutuhan waktu untuk mencapai kompetensi atau menguasai meteri.

\section{Pelaksanaan program pelatihan tata busana}

Proses pembelajaran dibagi menjadi dua tahapan yaitu belajar dalam kelas dan PBKL. Waktu pembelajaran di ruang kelas maksimal yaitu 10-11 bulan yang dilaksanakan pada Senin, Selasa, Rabu, Kamis dan Sabtu setiap pukul 10.00-12.00, kemudian PBKL selama satu Bulan (26 hari). Peserta dapat melakukan PBKL setelah benar-benar memenuhi syarat pada setiap mata bidangnya, syarat tersebut adalah bagian dari materi yang menjadi materi puncak pada setiap bidangnya. Seperti yang sudah dikemukakan sebelumnya, bahwa syarat bidang bordir adalah bordir baju, bidang desain yaitu membuat desain tiga dimensi, pada bidang kerajinan membuat peyet dan pada bidang jahit membuat kebaya

Instruktur menyampaikan materi dengan menggunakan penugasan perindividu yang berupa praktek adapun medianya sesuai dengan kebutuhan, namun yang lebih dominan digunakan adalah media percontohan yang menyesuaikan materi dan bidangnya. Dalam setiap materi pada semua bidang, peserta selalu mendapatkan tugas. Tugas tidak serta merta diberikan begitu saja, sambil peserta mengerjakan tugas/praktek, instruktur pada saat itu memberikan arahan langsung baik berupa ceramah maupun demonstrasi agar peserta benar-benar memahaminya. Metode yang digunakan dengan penugasan sebab program ini adalah program yang menitikberatkan pada praktek. Penggunaan metode praktek tidak terlepas dari dukungan sarana dan prasarana itu sendiri, tanpa sarana dan prasarana yang memadai penggunaan metode praktek tidak akan optimal bahkan tidak menjadi hambatan dalam proses pembelajaran terutama dalam proses penguasaan materi oleh para peserta.

Pendamping dan instruktur selalu melakukan pengecekan khusus terkait dengan bahan-bahan yang diperlukan agar tidak mengamati kekurangan ketersediaan. Sarana dan prasarana dapat dimanfaatkan oleh peserta di luar jam belajar selama peserta memiliki waktu luang, sarana dan prasarana dapat leluasa digunakan sebab semua peserta wajib tinggal di asrama. Jadi adanya sarana dan prasarana memang ditujukan untuk kelangsungan proses belajar, baik pemanfaatannya di dalam jam belajar (sesuai jadwal) maupun di luar jam belajar.

Dalam komunikasi maupun berinteraksi dengan peserta, instruktur dapat memahami kondisi peserta dalam menangkap materi pola (rumus pola). Saat beberapa peserta mengalami kesulitan dalam memahami apa yang diajarkan oleh instruktur, saat itulah instruktur berusaha sedemikian rupa agar materi pola atau lainnya dapat mudah dipahami oleh peserta. Maka saat itulah terjadi proses pengembangan atau peningkatan kemampuan instruktur. Instruktur mengembangkan dirinya seperti dalam hal komunikasi maupun dalam 


\section{Diklus : Jurnal Pendidikan Luar Sekolah, 1(1), Maret 2017, 114 Abdul Rohman Nurfaal}

pengembangan materi agar materi yang disampaikan tidak rumit dipahami oleh peserta

Setiap peserta pada umumnya dapat menguasai materi yang disampaikan oleh instruktur, namun bukan berarti peserta tidak mengalami kesulitan. Kesulitan-kesulitan ini dapat diatasi oleh peserta dengan bertanya kepada instruktur maupun kepada peserta lain, adanya sistem buka tutup mempunyai kelebihan yaitu penguasaan tingkatan materi yang berbeda-beda oleh setiap pesertanya karena perbedaan waktu masuk, peserta dengan penguasaan materi level awal tentu dapat bertanya kepada peserta lain yang tingkatan level materinya lebih tinggi.

Temuan-temuan terkait dengan pelaksanaan program didukung oleh Djuju Sudjana (2008: 92) bahwa pelaksanaan adalah pengimplementasian pelaksanaan, kemudian dalam proses pembelajaran terjadi interaksi anatara masukan sarana dengan masukan mentah.

\section{Evaluasi program pelatihan tata busana}

Evaluasi dilakukan di dalam kelas dan di luar kelas. Pelaksanaan evaluasi di dalam kelas dilakukan setiap pertemuan oleh instruktur dan pendamping, instruktur dan pendamping mengevaluasi peserta tidak menggunakan tes, melainkan menggunakan pengamatan secara langsung terhadap masing-masing peserta serta melihat dari hasil penugasannya. Kemudian instruktur memberikan arahan dan bimbingan atau umpan balik langsung kepada setiap peserta maupun kelompok pada saat itu juga.

Umumnya setiap peserta mempunyai umpan balik yang berbeda dengan yang lain. Evaluasi yang melihat dari hasil tugas juga tidak jauh berbeda, peserta menyerahkan hasil penugasan kepada instruktur kemudian saat itu juga instruktur memberikan umpan balik atau tanggapan terkait dengan penugasan tersebut. Pengamatan yang dilakukan oleh instruktur saat proses belajar maupun pengamatan terhadap hasil penugasan bertujuan supaya peserta yanng melenceng dari rambu-rambu, dapat segera diarahkan agar proses dan hasilnya menjadi optimal. Evaluasi yang dilakukan dalam kelas lebih memfokuskan pada pencapaian peserta, agar peserta sepenuhnya menguasai materi yang diberikan kepada instruktur.

Produk yang dihasilkan peserta digunakan oleh instruktur sebagai media atau model percontohan. Produk juga dipamerkan namun dalam event tertentu saja, padahal produk-produk tersebut jumlahnya banyak serta mempunyai kualitas yang tidak kalah bagus.

Evaluasi yang dilakukan di luar kelas yang disebut sebagai evaluasi triwulan atau rapat triwulan yang dilaksanakan setiap tiga bulan sekali, dalam evaluasi ini melibatkan semua instruktur, pendamping, dan pegawaipegawai lainnya. Dalam evaluasi ini tidak hanya membahas mengenai peserta, melainkan membahas mengenai sarana dan prasarana, waktu, PBKL dan penempatannya. 


\section{Diklus : Jurnal Pendidikan Luar Sekolah, 1(1), Maret 2017, 115 \\ Abdul Rohman Nurfaal}

PBKL menjadi ajang pembuktian bagi peserta bahwa dirinya benar-benar sudah menguasai apa yang telah diajarkan oleh instruktur-instruktur, dan belajar bekerja pada sesuai dengan kenyataan/keadaan yang ada. Tindaklanjut dari PBKL peserta akan ditanyai terkait rencana kerja, peserta yang sudah memiliki gambaran rencana tempat kerja oleh BPRSW untuk akses mediasi di tempat kerja, sedangkan bagi peserta yang belum memiliki gambaran akan diberikan pilihan-pilihan oleh BPRSW di tempat kerja yang sudah menjalin kerjasama. Apabila kinerja dari peserta saat PBKL itu memuaskan, peserta dapat direkrut pada badan usaha tersebut. Contohnya pada modiste yang dimiliki oleh instruktur bidang menjahit yaitu Ibu SW, beliau merekrut tiga peserta PBKL untuk menjadi karyawan di modistenya atau bagian dari modistenya. Setelah peserta bekerja akan dimonitoring perkembangan ditempat kerjanya dalam jangka waktu tiga tahun dalam setiap bulannya. Hal ini dukung oleh Suharsimi Arikunto dan Cepi Syafrudin Abdul Jabar (2009: 20) bahwa evaluasi merupakan kegiatan pengumpulan informasi yang digunakan untuk menentukan alternatif yang tepat dalam mengambil suatu keputusan.

Hasil dan manfaat pelatihan, dalam hal ini yang lebih merasakannya yaitu peserta, namun instruktur dan pendamping juga dapat mengetahui manfaat yang diperoleh peserta dari hasil pelatihan. Hasil dan manfaat yang diperoleh peserta pada saat pelatihan peserta yaitu peserta mempunyai keterampilan terkait dengan menjahit, membordir, desain dan membuat pernak-pernik. Dalam proses untuk menguasai keterampilan tersebut membentuk sikap peserta seperti kesabaran, ketekukan, ketelitian, meningkatkan kreativitas/ide. Manfaat dalam penguasaan keterampilannya yaitu peserta menjadi lebih percaya diri dengan keterampilan yang dimiliki, dan diharapkan mampu menunjang kehidupannya terutama dalam perekonomian atau peserta mampu bekerja maupun mendirikan usaha jahit/modiste. Hal ini mengarah pada cara pemenuhan kebutuhan ekonomi yang wajar atau tidak menyimpang, sebab di luar sana banyak cara-cara yang tidak sesuai dengan norma-norma masyarakat.

Hasil dan manfaat program pelatihan tata busana bagi peserta sesuai dengan manfaat pelatihan yang dikemukakan oleh Ikka Kartika A. Fauzi (2011: 15), yaitu adanya peningkatan kemampuan, mengembangkan sikap-sikap positif yang dibentuk selama proses pelatihan, kemudian bekal kemampuan dan sikap yang dimiliki peserta tersebut akan berguna dalam pemenuhan kebutuhan ekonominya melalui lingkungan kerja. Hal ini juga sesuai dengan temuan Muhammad Adil Arnady Iis Prasetyo (vol. 3 no. 1 tahun 2016) yang menyatakan bahwa hasil suatu program pelatihan dapat dilihat dari adanya peningkatan keterampilan, sikap, dan pengetahuan.

Pendukung program yang dirasakan oleh instruktur yaitu koordinasi antar sumber daya yang saling mendukung, seperti adanya 


\section{Diklus : Jurnal Pendidikan Luar Sekolah, 1(1), Maret 2017, 116 Abdul Rohman Nurfaal}

pendamping yang berperan untuk selalu memotivasi peserta.

Sumber daya pendukung lainnya adalah ketersediaan sarana dan prasarana untuk kelancaran proses belajar bagi peserta dan instruktur. Selain ketersediaan sarana dan prasarana juga dapat dimanfaatkan oleh peserta diluar jam belajar selama peserta tersebut mau memanfaatkan waktu luangnya. Instruktur merupakan tokoh yang penting dalam pelaksanaan program tata busana. instruktur berperan dalam mengolah komponen-komponen pelatihan khususnya dalam memberi dukungan kepada peserta.

Pendukung program tersebut didukung oleh pendapat yang dikemukakan oleh Djuju Sudjana (2008: 92) bahwa dalam proses pembelajaran merupakan interaksi antara masukan sarana dan masukan mentah. Jadi ketersediaan sumber daya pendukung pada masukan sarana dan peserta sangat diperlukan untuk melaksanakan program pelatihan

Penghambat program yang dirasakan oleh peserta yaitu kualitas yang tidak stabil pada mesin jahit/bordir. Kemudian ada mesin bordir yang baru, namun sudah mengalami kerusakan. Menurut informasi yang disampaikan instruktur, mesin bordir baru yang rusak adalah mesin bordir tiruan sehingga kualitasnya lebih rendah di banding dengan merk yang asli, dari segi harganya memang yang tiruan lebih murah dibandingkan dengan yang asli namun kualitasnya kalah jauh, terbukti dua mesin bodir asli yang usianya lebih tua namun kualitasnya bagus, daya tahan (keawetannya) sampai sekerang masih baik.

Faktor penghambat lainnya yaitu kesulitan yang dirasakan oleh penyedia bahan ataupun alat. Bahan atau alat harus kompatibel dengan komponen-komponen lainnya. Alat atau bahan terserbut tidak selalu ada di toko atau kehabisan stok, bahkan toko lainnya juga demikian. Faktor penghambat ini mengarah pada sarana dan prasarana, adanya permasalahan terkait dengan sarana dan prasarana dapat menghambat program di dukung oleh Ikka Kartika A Fauzi (2011: 116) bahwa kualitas sarana dan prasarana sangat berpengaruh terhadap keberlangsungan proses pembelajaran, jika kurang diperhatikan maupun ketersediannya kurang maka dapat menghambat proses pelaksanaan program

\section{Kesimpulan}

Berdasarkan hasil penelitian dan pembahasan mengenai pelaksanaan program pelatihan tata busana di BPRSW DIY, dapat disimpulkan sebagai berikut:

1. Pada perencanaan meliputi perencanaan peserta, materi, media, metode, waktu, sarpras, instruktur, dan waktu. Perencanaan melalui kordinasi penyelenggara dan instruktur, dalam menentukan kompononen sesuai dengan kebutuhan, sedangkan peran penyelenggara adalah menyediakan komponen yang dibutuhkan oleh instruktur dalam mendukung program pelatihan. 
2. Pada pelaksanaannya, instruktur mempunyai peran dalam mengolah komponen-komponen seperti materi, sarpras, media, metode, peserta, dan memanfaatkan waktu. Kemudian setiap peserta diberikan materi yang berbeda sesuai dengan pencapaiannya.

3. Evaluasi dilakukan di dalam kelas dan di luar kelas. Evaluasi di dalam kelas dilakukan oleh instruktur dan pendamping, instruktur melakukan evaluasi melalui pengamatan langsung pada setiap peserta, kemudian langsung ditindaklanjuti dengan memberikan arahan dan bimbingan. Pada evaluasi triwulan melibatkan seluruh pegawai BPRSW DIY, dimana komponenkomponen yang dievaluasi tidak hanya pencapaian peserta. Produk yang dihasilkan peserta dapat dipamerkan dan dijadikan sebagai model percontohan. Faktor pendukung yaitu adanya pendamping yang berperan untuk memotivasi, keuletan instruktur, ketersediaan sarpras. Selain itu peserta boleh memanfaatkan sarpras di luar jam belajar untuk belajar atau menyelesaikan tugas. Sedangkan faktor penghambatnya kualitas sarana seperti mesin jahit dan mesin bordir tidak stabil.

\section{Saran}

Berdasarkan temuan penelitian, ada beberapa saran yang disampaikan yaitu:

1. Perlunya perluasan pemasaran terhadap produk-produk peserta, yang harapannya
BPRSW DIY maupun alumninya semakin dikenal baik oleh masyarakat

2. Dalam hal pengadaan sarpras hendaknya lebih memperhatikan kualitas. Sebab kualitas yang baik akan mempermudah dan mengoptimalkan proses belajar. Kemudian perlu perbaikan secara tanggap dan cepat terhadap mesin yang bermasalah.

3. Dalam pengadaan alat dan bahan perlunya membangun jaringan/networking dari instruktur untuk mempermudah pengadaan alat dan bahan yang sesuai kebutuhan.

\section{Daftar Pustaka}

Ambar Teguh Sulistiyani. (2004). Kemitraan dan Model-Model Pemberdayaan. Yogyakarta: Gava Media.

Badan Pusat Statistik. (2016). Tingkat Pengangguran Terbuka (TPT) Menurut Provinsi, 1986-201. https://www.bps.go.id/linkTabelStatis/ view/id/981 (diakses 14 April 2016) . (2016). Laporan Bulanan Data Sosial Ekonomi Juni 2016. Jakarta: Badan Pusat Statistik.

Djuju Sudjana. (2008). Evaluasi Program Pendidikan Pendidikan Luar Sekolah untuk Pendidikan Nonformal dan Pengembangan Sumberdaya Manusia. Bandung: PT Remaja Rosdakarya.

Ikka Kartika A. Fauzi. (2011). Mengelola Pelatihan Partisipatif. Bandung: Alfabeta.

Kartini Kartono. (2015). Patologi Sosial Jilid 1. Jakarta: Raja Grafindo Persada.

Muhammad Adil Arnady Iis Prasetyo. (2016). Evaluasi Program Kecakapan Hidup di Sanggar Kegiatan Belajar Bantul, Yogyakarta. Jurnal Pendidikan dan Pemberdayaan Masyarakat, 3(1), 6074.

Oemar Hamalik. (2007). Manajemen Pelatihan Ketenagakerjaan 
Pendekatan Terpadu Pengembangan Sumber Daya Manusia. Jakarta: Bumi Aksara.

Peraturan Presiden No 18 Thn 2014 tentang Perlidungan dan Pemberdayaan Perempuan dan Anak dalam Konflik Sosial.

Saleh Marzuki. (2012). Pendidikan Nonformal Dimensi dalam Keaksaraan Fungsional, Pelatihan dan Andragogi. Bandung: PT Remaja Rosdakarya.

Sub Direktorat Statistik Politik dan Keamanan. (2015). Katalog BPS Statistik Kriminal 2015. Jakarta: Badan Pusat Statistik.

Suharsimi Arikunto dan Cepi Safrudin Abdul Jabar. (2009). Evaluasi Program Pendidikan Pendoman Teoritis Praktis Bagi Mahasiswa dan Pratisi Pendidikan Edisi kedua. Jakarta: Bumi Aksara

Tim Dosen AP UNY. (2000). Manajemen Pendidikan. Yogyakarta: UNY Press.

Undang-Undang Nomor 11 Tahun 2009 tentang Kesejahteraan Sosial. 